\title{
The reaction of the thyroid gland to the thyrotropic hormone "load" in high and low- yielding cows
}

\author{
V.I. Eremenko*, G.A. Gorozhankina, N.V. Vanina, S.I. Shuklin, and A.I. Blednov \\ Kursk State Agricultural Academy named after I.I. Ivanov, K. Marx Str., 70, 305021, Kursk, Russia
}

\begin{abstract}
The studies were carried out on cows of Holstein black-andwhite breed. 2 groups of 10 heads each were formed. The milk yield for lactation was 10 thousand $\mathrm{kg}$ in the first group, and -5 thousand $\mathrm{kg}$ in the second group. Blood was collected from the subcaudal vein monthly during lactation. $T_{3}$ and $T_{4}$ were determined in the blood serum. The functional "load" on the thyroid gland was performed at the peak of lactation (3 months) and at its end - at 9 months. The TSH preparation at a dose of $0.5 \mathrm{u} / \mathrm{kg}$ of live weight was administered intramuscularly on an empty stomach before morning feeding. $\mathrm{T}_{3}$ and $\mathrm{T}_{4}$ hormones in the blood were determined before the injection of TSH and 0.5 one and two hours after the injection. $K_{\text {ath }}$ was calculated using the formula $T_{1}-T_{0} / T_{0}$ where $K_{\text {ath }}$ is the coefficient of activity of thyroid hormones. $T_{0}-T_{3}$ and $T_{4}$ levels before TSH injection $\mathrm{T}_{1}-\mathrm{T}_{3}$ and $\mathrm{T}_{4}$ levels 2 hours after TSH injection. During lactation, the level of milk production and thyroid hormones varies inversely with the average daily milk yield. During the period of high milk productivity $\left(2,3,4\right.$ months of lactation), the concentration of $T_{3}$ and $T_{4}$ in both groups was low, and later increased and was maximum in the 8th month of lactation. The functional reserves of the thyroid gland in highyielding cows in 3 and 9 months of lactation are lower in relation to lowyielding cows.
\end{abstract}

\section{Introduction}

The main reserve for increasing the level of livestock productivity is the realization of its genetic potential, taking into account the physiological and biochemical characteristics of their body [1-3]. When assessing the future forecast productivity, it is necessary to take into account the interior indicators. Blood is one of the available objects for assessing the physiological state of the animal's body. Therefore, the study of individual characteristics of animals will allow to select purposefully animals with a high genetic potential of their productivity. In this regard, special attention should be paid to the study of the hormonal status that allows to study the productivity formation. The study of the thyroid gland state, the functioning of which is directly related to the formation of animal productivity, is of particular interest. Therefore, the study of the thyroid function state of the thyroid gland in cattle will reveal the persistent mechanisms of the formation of milk productivity in relation

* Corresponding author: vic.eriomenko@yandex.ru 
to the functional reserves of the thyroid gland [4-12]. To identify the functional reserves of the thyroid gland in experimental endocrinology, the thyroid-stimulating hormone TSH is used. The functional "load" with thyroid-stimulating hormone allows to set the functioning limits of the thyroid gland [13]. In this regard, the knowledge of the functional reserves of the thyroid gland in cattle will allow to use the data obtained in breeding work with cattle.

Purpose. To determine the functional reserves of the thyroid function of the thyroid gland in productive cows by the method of functional "load" with the help of thyroidstimulating hormone.

\section{Research materials}

The studies were carried out on the population of animals of the Holstein black-and-white breed. For the experiment, two groups of ten heads each were selected. Productivity in the first group for the previous lactation was 10 thousand $\mathrm{kg}$, and in the second -5 thousand $\mathrm{kg}$. The diets were balanced for the main nutrients. For the biochemical analysis of thyroxine and triiothyronine, blood was collected from the subcaudal vein monthly during lactation. In the blood (serum), $\mathrm{T}_{3}$ and $\mathrm{T}_{4}$ were examined by enzyme immunoassay. In 3 and 9 months of lactation, TSH was injected. TSH was administered in an amount of 0.5 units per $\mathrm{kg}$ of live weight intramuscularly. TSH injection was performed on an empty stomach before the first feeding. $\mathrm{T}_{3}$ and $\mathrm{T}_{4}$ hormones in the blood were determined before the injection of TSH and 0.5 one and two hours after the injection. $\mathrm{K}_{\text {ath }}$ was calculated using the formula $T_{1}-T_{0} / T_{0}$ where $K_{\text {ath }}$ is the coefficient of activity of thyroid hormones. $T_{0}-T_{3}$ and $\mathrm{T}_{4}$ levels before TSH injection $\mathrm{T}_{1}-\mathrm{T}_{3}$ and $\mathrm{T}_{4}$ levels 2 hours after TSH injection. Thyroid hormones $\mathrm{T}_{3}$, T4 were determined by the enzyme immunoassay. The digital experimental material was biometrically processed.

\section{Results of the study and their discussion}

In the postpartum period ( 1 month of lactation), the $\mathrm{T}_{4}$ level in the 1 st group of cows was $35.1 \pm 2.0 \mathrm{nmol} / 1$, and in the $2 \mathrm{nd}$ group the concentration was $37.7 \pm 1.6 \mathrm{nmol} / 1$, Figure 1 .
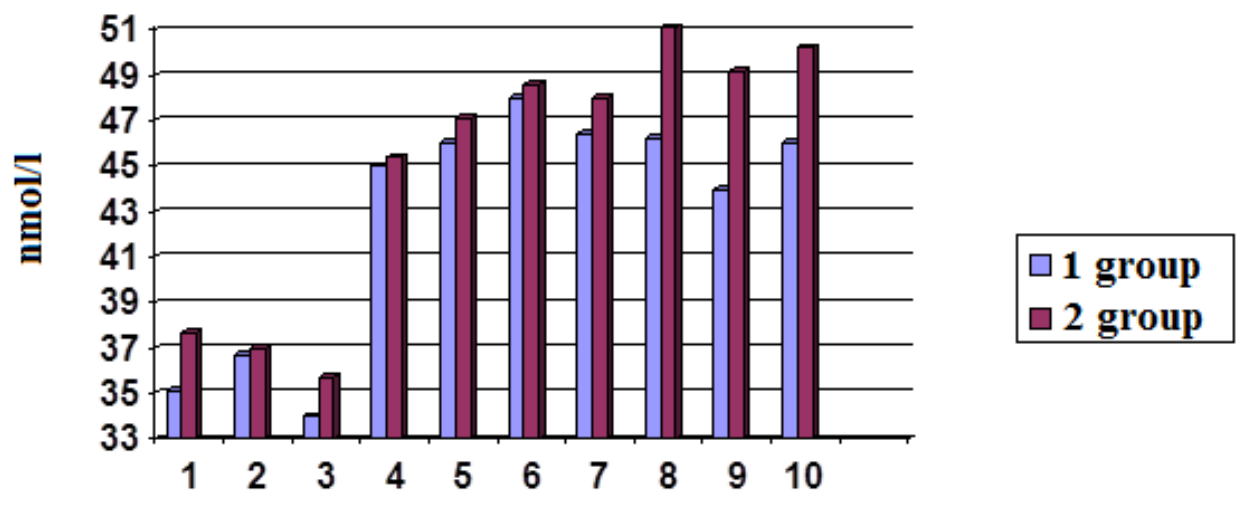

\section{Lactation month}

Fig.1. Dynamics of the T4 level in the blood in lactating cows with different levels of milk production.

By the 3rd month of lactation, $\mathrm{T}_{4}$ was characterized by a slow and dynamic decrease in 
this hormone to the peak of lactation. During the period of high milk productivity (3 months of lactation), the $\mathrm{T}_{4}$ index in the 1 st group was $34.0 \pm 1.5 \mathrm{nmol} / \mathrm{l}$, and in cows in the group with lower productivity, the $\mathrm{T}_{4}$ level was $35.7 \pm 2.1 \mathrm{nmol} / \mathrm{l}$. After the peak of lactation, there was a decrease in the average daily milk yield, and the level of thyroxine synthesis, on the contrary, increased. Thus, there was an inverse interrelation between the value of milk yield and the level of thyroxine synthesis. By the fourth month of lactation, there was a sharp increase in $T_{4}$ in two experimental groups. The hormone concentration during this period was $45.0 \pm 2.2$ in the first group and $45.4 \pm 3.0$ in the group of cows with lower milk yields. With a decrease in average daily milk yields, starting from the 4th month of lactation, the hormone level in the high-yielding group of cows was $45.0 \pm 2.2 \mathrm{nmol} / \mathrm{l}$ $(\mathrm{P}<0.05$ by the $3 \mathrm{rd}$ month of lactation), and in the compared group, the thyroxine level was $45.4 \pm 3.0 \mathrm{nmol} / \mathrm{l}$. Further, in the 6 th month of lactation, these indicators were at the level of $48.0 \pm 2.0 \mathrm{nmol} / 1$ in the highly productive group and $48.6 \pm 1.5 \mathrm{nmol} / 1$, in the second group. The study of the thyroxine level in the seventh, eighth, ninth and tenth months of lactation showed that its concentration in the blood was $46.4 \pm 1.9 \mathrm{nmol} / 1,46.2 \pm 2.4 \mathrm{nmol} / 1,44.0 \pm 2.0$ $\mathrm{nmol} / \mathrm{l}$, and $46.0 \pm 2.1 \mathrm{nmol} / \mathrm{l}$, respectively, by month. The study of this indicator in the second group during the same months of lactation indicates that the concentration of this hormone in this group was higher and amounted to $48.0 \pm 2.0 \mathrm{nmol} / 1,51.1 \pm 2.1 \mathrm{nmol} / \mathrm{l}$, $49.2 \pm 2.0 \mathrm{nmol} / 1,50.2 \pm 2.4 \mathrm{nmol} / 1 \mathrm{respectively,} \mathrm{for} \mathrm{the} \mathrm{months} \mathrm{of} \mathrm{lactation.} \mathrm{Analyzing} \mathrm{in}$ general the results of thyroxine dynamics in the blood serum of experimental cows indicate that an inverse interrelation has been established between the average daily milk yields and the level of the studied hormone. The survey research of $T_{3}$ in the blood serum of lactating cows are presented in Figure 2.
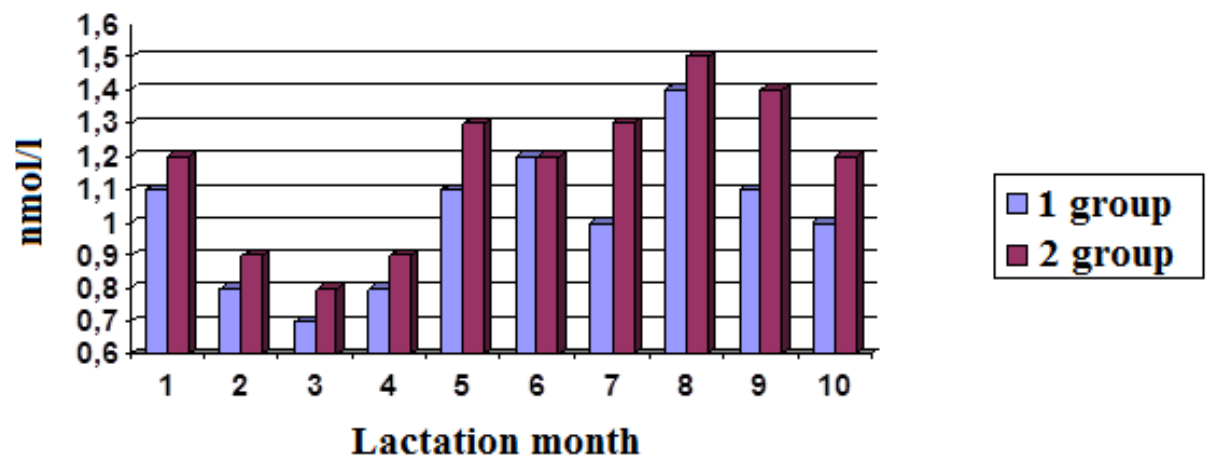

Fig. 2. Dynamics of the $T_{3}$ level in the blood of experimental cows of different levels of milk productivity.

In the postpartum period ( 1 month of lactation), the $T_{3}$ level in the 1 st group of cows was $1.1 \pm 0.07 \mathrm{nmol} / 1$ and in the second $-1.2 \pm 0.09 \mathrm{nmol} / 1$, which indicates the same level of $\mathrm{T}_{4}$ synthesis. With an increase in the average daily milk yield, the dynamics of $\mathrm{T}_{3}$ was characterized by a gradual decrease in this indicator to the peak of lactation (3 months). During the period of high milk productivity ( 3 months of lactation), the $T_{3}$ value in the 1 st group was $0.7 \pm 0.08 \mathrm{nmol} / \mathrm{l}$, and in the group of low-yielding cows, the $\mathrm{T}_{3}$ value was $0.8 \pm 0.08 \mathrm{nmol} / \mathrm{l}$. In the following months of lactation, changes in triiodothyronine occurred in the direction of an increase against the background of a decrease in the milk productivity of cows. By the fourth month of lactation, there was a tendency to $T_{3}$ increase, and in the fifth month there was a sharp rise in this hormone, which lasted until the eighth month of lactation. Before the end of lactation, in the eighth month, the concentration of triiodothyronine in the first group was $1.4 \pm 0.1 \mathrm{nmol} / \mathrm{l}$, and in the second group $-1.5 \pm 0.1$ 
nmol/l. By the tenth month of lactation, the concentration of triiodothyronine in the two experimental groups decreased. Analyzing in general the results of thyroxine dynamics in the blood serum of experimental cows indicate that an inverse interrelation has been established between the average daily milk yields and the level of the studied hormone.

For a more objective functional state of the thyroid function of thyroid gland in experimental cows with high and low levels of productivity in 3 and 9 months of lactation, the experimental cows were subjected to functional "loads" with the help of thyroidstimulating hormone (TSH). The scheme of "loads" is described in the section "Research materials". This method is considered to be classic in experimental endocrinology. Since the highest milk productivity in both groups of cows was observed in the 3rd month of lactation, during this lactation period, we performed a functional "load" with thyroidstimulating hormone to detect the thyroid-synthesizing function of the thyroid gland. At the end of lactation, a similar functional "load" was performed on high-and low-yielding experimental cows. Data on the dynamics of $\mathrm{T}_{4}$ after TSH injection at the peak of lactation are shown in Figure 3.
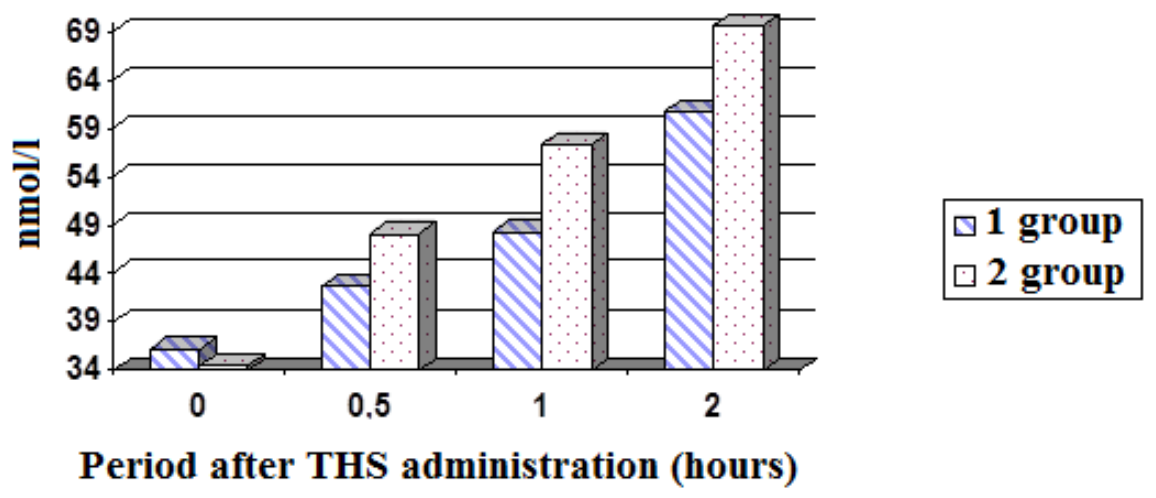

Fig. 3. $\mathrm{T}_{4}$ level in the blood of lactating cows at the peak of lactation (3 months) after TSH injection.

The functional load on the thyroid function of thyroid gland indicates that $\mathrm{T}_{4}$ level before TSH injection in the first experimental group was $36.1 \pm 1.3 \mathrm{nmol} / 1$, and in the second low-yielding group of cows, the $\mathrm{T}_{4}$ concentration was at the level of $34.5 \pm 1.4 \mathrm{nmol} / \mathrm{l} .30$ minutes after the TSH injection, the hormone levels in the experimental groups of lactating cows increased. In the 2nd low-yielding group, the hormone parameters increased by 39.7 $\%$ and in absolute units it was $48.2 \pm 1.5 \mathrm{nmol} / 1$. In the $1 \mathrm{st}$ high-yielding group of cows, the increase in thyroxine synthesis occurred by $18.1 \%$ and in absolute units of measurement it was $42.6 \pm 2.1 \mathrm{nmol} / 1$.

Within 1 hour after the injection, the hormone index in the low-yielding group increased by $66 \%$, and in the first group by $34 \%$. During the experiment, high values of the hormone were observed in both groups two hours after TSH injection. In relation to the data before TSH injection, the hormone level increased by $101.4 \%$, and in absolute values up to the level of $69.5 \pm 2.6 \mathrm{nmol} / 1$. In the 1 st group, thyroxine increased by $68.1 \%$ and its absolute values were $60.7 \pm 2.3 \mathrm{nmol} / \mathrm{l}$. Based on statistical data, differences between the experimental groups of cows were noted one and two hours after TSH injection $(\mathrm{P}<0.05)$. The coefficient of thyroid hormones activity $\left(\mathrm{KathT}_{4}\right)$ in the first group was 0.69 , and in the second - 1.02. Thus, high-milk productivity is characterized by low KathT 4 .

Data on the "load" of the same animals in 9th month of lactation were presented in Figure 4. 


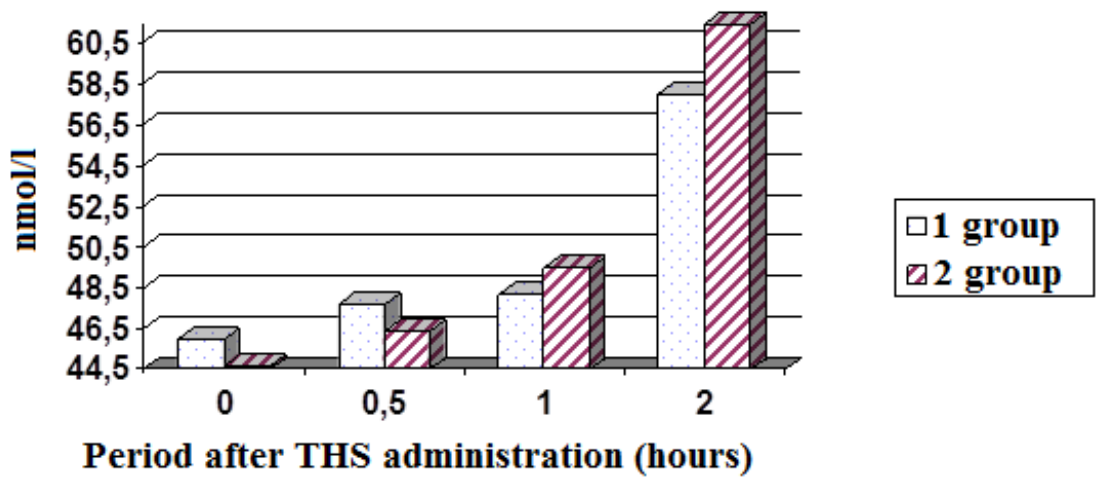

Fig. 4. T4 level in the blood of lactating cows in the 9th month of lactation after TSH injection.

From the data shown in Figure 4, it can be seen that the $\mathrm{T}_{4}$ level in the first experimental high-yielding group of cows was $46.0 \pm 2.3 \mathrm{nmol} / \mathrm{l}$, and in the second low-yield group the $\mathrm{T}_{4}$ concentration was at the level of $44.7 \pm 2.3 \mathrm{nmol} / \mathrm{l}$. After the functional load on the thyroid function of thyroid gland TSH, the concentration of the hormone increased. In the first group, the values reached the level of $47.7 \pm 2.0 \mathrm{nmol} / 1$, and in the second group - $46.4 \pm 1.8$ $\mathrm{nmol} / \mathrm{l}$. After 1 hour from the start of TSH administration in the low-yielding group, the level reached $49.5 \pm 2.0 \mathrm{nmol} / \mathrm{l}$, and in the first high-yielding group of lactating cows, it rose to $48.2 \pm 2.1 \mathrm{nmol} / 1$. The highest level of $\mathrm{T}_{4}$ in the experimental cows was observed two hours after the TSH injection and did not depend on the level of cow productivity. In the high-yielding group of cows, compared to the data before the TSH administration, the increase in the hormone occurred by $26 \%$, and in the low-yielding group, this increase was $37.3 \%$. The level of thyroid response to the TSH load in the 9th month of lactation occurred to a lesser extent than during the peak of lactation. The coefficient of thyroid hormone activity (T4) was lower in the 9th month of lactation than during the period of high milk productivity.

$\mathrm{K}_{\mathrm{ath}} \mathrm{T}_{4}$ in the high-yielding group was equal to 0.26 in the first group, and in the lowyielding group this indicator was equal to 0.38 .

The dynamics of changes in the $\mathrm{T}_{3}$ level after injection at the peak of lactation is shown in Figure 5.

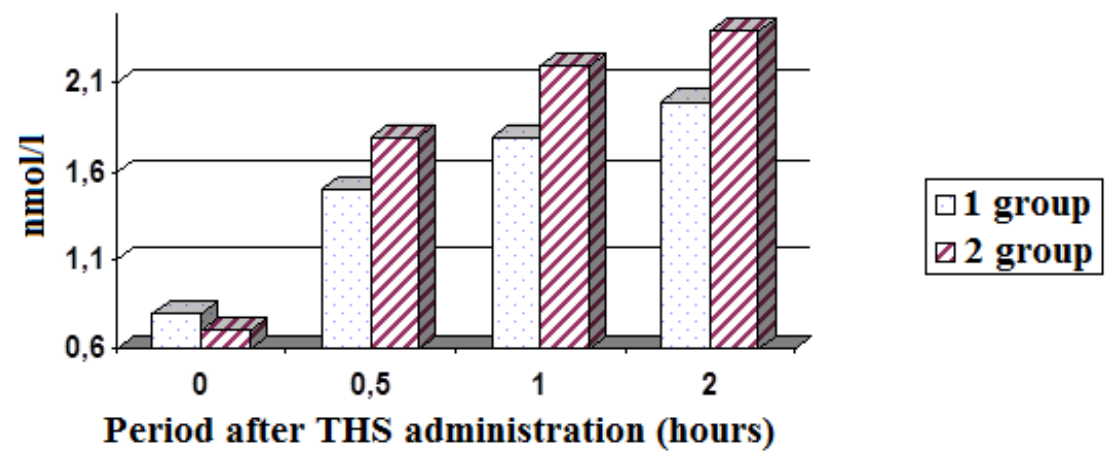

Fig. 5. Triiodothyronine level in the blood of lactating cows at the peak ( 3 month) of lactation after TSH administration.

The results of functional load on the thyroid gland during the period of high milk yields (3 months of lactation) are shown in Figure 5. The concentration of triiodothyronine before 
TSH injection in the first high-yielding group of cows was $0.8 \pm 0.08 \mathrm{nmol} / 1$, and it was almost at the same level in the second low-yielding group and was $0.7 \pm 0.07 \mathrm{nmol} / 1$. After the functional load in 30 minutes, the hormone index in the high-yielding group of cows increased by $87.5 \%$ and reached the level of $1.5 \pm 0.13 \mathrm{nmol} / \mathrm{l}$, and in the compared lowyielding group, the hormone concentration increased more than 2 times during this period, and the hormone values reached the level of $1.8 \pm 0.12 \mathrm{nmol} / \mathrm{l}$. As in the previous indicators, the highest concentrations of $\mathrm{T}_{3}$ after TSH injection occurred after 2 hours. In the highyielding group of cows, the increase in $\mathrm{T}_{3}$ concentration was 2.5 times $(\mathrm{P}<0.05)$, and in the low-yielding group, this increase was more than 3 times $(\mathrm{P}<0.05)$.

After TSH injection, the differences between the compared groups were statistically significant $(\mathrm{P}<0.05) . \mathrm{K}_{\mathrm{ath}} \mathrm{T}_{3}$ in the high-yielding lactating group of cows was at the level of 1.5 , and in the second low-yielding group was 2.43 .

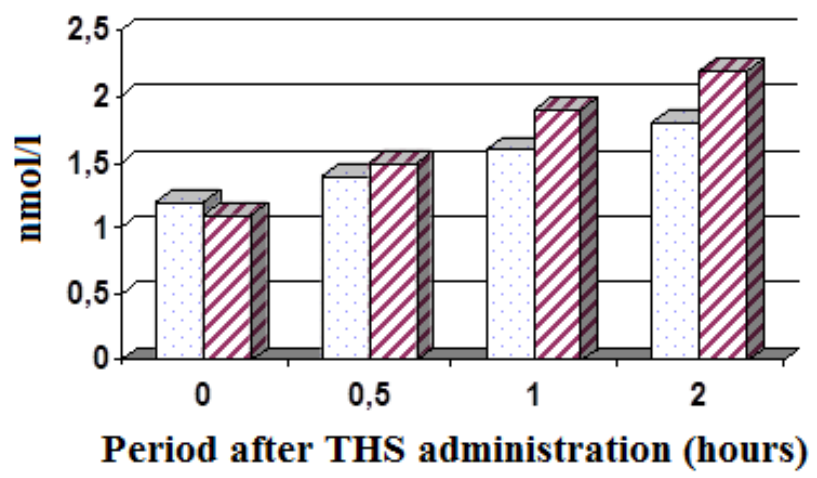

Fig. 6. $T_{3}$ level in the blood of lactating cows in the 9th month of lactation after TSH injection.

Figure 6 shows the results of the $\mathrm{T}_{3}$ study after the functional TSH load on the thyroid gland in the 9th month of lactation in cows with different milk productivity. The concentration of this hormone before the start of the experiment in the first high-yielding group was $1.2 \pm 0.1 \mathrm{nmol} / \mathrm{l}$, and in the low-yielding group this indicator was slightly lower, and reached the level of $1.1 \pm 0.09 \mathrm{nmol} / \mathrm{l}$. After the TSH injection, after 30 minutes, the concentration of the hormone in high-yielding cows reached the level of $1.4 \pm 0.10 \mathrm{nmol} / \mathrm{l}$, and in the low-yielding group, this indicator stopped at $1.5 \pm 0.12 \mathrm{nmol} / 1$. As in previous studies, the maximum functional activity of the thyroid gland was reached 2 hours after TSH injection. The maximum level of $\mathrm{T}_{3}$ during this period in the first group reached $1.8 \pm 0.13 \mathrm{nmol} / \mathrm{l}$, and in the compared low-yielding group, the concentration of the hormone was $2.2 \pm 0.15 \mathrm{nmol} / 1 . \mathrm{K}_{\mathrm{ath}} \mathrm{T}_{3}$ in the first high-yielding group of cows was 0.5 ; and in the second group - 1.0 .

Thus, in all phases of lactation ( 3 months) and ( 9 months), the coefficients of thyroid hormones activity are higher in low-yielding animals in relation to high-yielding ones. Such results can be used in breeding work to predict the future milk productivity of animals at an early age.

\section{Conclusions}

1. The concentration of thyroid hormones in the blood of lactating cows varies inversely with the average daily milk yield.

2. Thyroid activity of the thyroid gland at the peak of lactation decreases, followed by its increase by the end of lactation.

3. In all phases of lactation ( 3 months) and ( 9 months), the coefficients of thyroid hormones 
activity are higher in low-yielding animals in relation to high-yielding ones.

\section{References}

1. V.I. Eremenko, V.M. Kretova, Bulletin of the Kursk State Agricultural Academy 3-P, 16-18 (2008)

2. V.I. Eremenko, Functional reserves of the endocrine system in predicting milk productivity: monograph, 194 (Kursk: Publishing house of the Kursk State Agricultural Academy, 2010)

3. R.M. Solovyov, The use of indicators of the functional activity of the thyroid gland in the selection of dairy cattle, dis. ... cand. biol. sc., 140 (Velikiye Luki, Velikiye Luki State Agricultural Academy, 2011) http://www.mgavm.ru/library/doc/diploms/ed-83. pdf

4. A.I. Afanasyeva, I.N. Zavyalova, Functional state of the thyroid gland in goats of the Gorno-Altai downy breed during lactation, Modern technological and breeding aspects of the development of animal husbandry in Russia: proceedings of the III International Scientific and Practical Conference-Dubrovitsy, Research Institute of Animal Husbandry 2, 231-234 (2005)

5. A.I. Afanasyeva, V.A. Sarychev, S.S. Knyazev, Bulletin of the Altai State Agrarian University 6 (164), 97-102 (2018)

6. B.K. Balabaev, M.A. Derho, Agroindustrial Complex of Russia 23/3, 640-645 (2016)

7. T.L. Solovyova, V.V. Tsyupko, Agricultural biology 9, 96-99 (1984)

8. S.V. Dezhatkina, N.A. Lyubin, M.E. Dezhatkin, Bulletin of the Ulyanovsk State Agricultural Academy 1 (33), 46-49 (2016)

9. D.B. Demin, Journal of Medical and Biological Research 6 (2), 115-127 (2018)

10. T.Yu. Demidova, O.R. Galieva, The role and place of thyroid hypofunction in the development of metabolic syndrome, 492-493 (Man and Medicine: Russian nation. Congress, M., 2008)

11. N.L.M. Lara, V.A. Silva, H. Chiarini-Garcia [et. al.], General and Comparative Endocrinology 299, 113593 (2020) (doi.org/10.1016/j.ygcen.2020)

12. M.A. Derkho [et al.], International Journal of Advanced Biotechnology and Research 10 (2), 267-277 (2019)

13. V.P. Radchenkov, V.A. Matveev, E.V. Butrov, Endocrine regulation of growth and productivity of farm animals 159 (Moscow VO "Agropromizdat", 1991) 